to

make

my

name good 



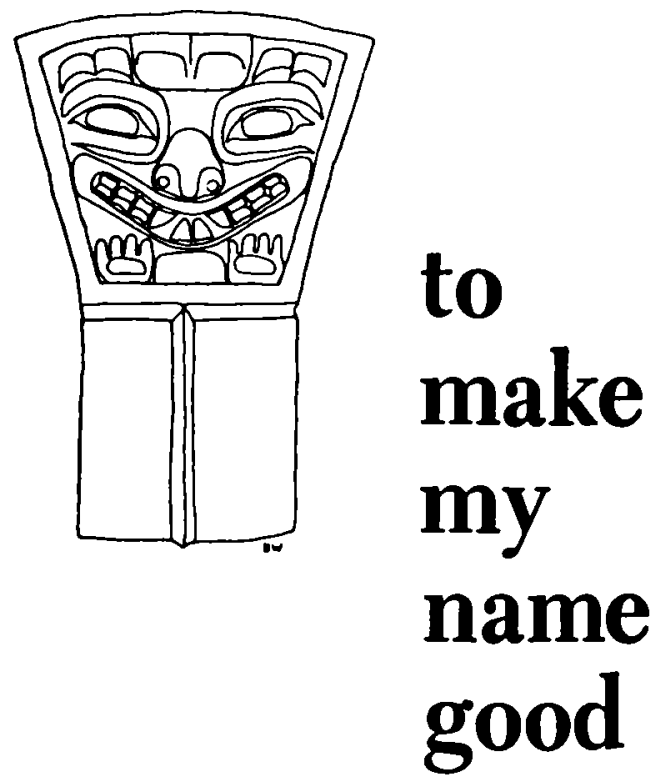

A Reexamination of the Southern Kwakintl Potlatch

\section{Philip Drucker} and

Robert F. Heizer 
UNIVERSITY OF CAIIFORNIA PRESS

BERKELEY AND LOS ANGELES, CALIFORNIA

CAMBRIDGE UNIVERSITY PRESS

LONDON, ENGLAND

COPYRIGHT (C) $1967, \mathrm{BY}$

THE REGENTS OF THE UNIVERSTTY OF CALIFORNIA

LIBRARY OF CONGRESS CATALOG CARD NUMBER: 67-16839

PRINTED IN THE UNITED STATES OF AMERICA 